\title{
The Self-translator as Cultural Mediator: In Memory of Jabra Ibrahim Jabra
}

\author{
Nibras A. M. Al-Omar ${ }^{1}$ \\ ${ }^{1}$ Faculty of Arts, Zarqa University, Jordan \\ Correspondence: Nibras A. M. Al-Omar, Faculty of Arts, Zarqa University, Jordan. E-mail: \\ nibrasmahmoud@yahoo.ca
}

Received: July 1, 2012 Accepted: July 31, 2012 Online Published: October 19, 2012

doi:10.5539/ass.v8n13p211 URL: http://dx.doi.org/10.5539/ass.v8n13p211

This research is funded by the Deanship of Research and Graduate Studies in Zarqa University/Jordan

\begin{abstract}
The present paper investigates the self-translation action as practiced by a bilingual writer: Jabra Ibrahim Jabra who has rendered a chapter of his novel Hunters in a narrow Street, written originally in English, back into Arabic. It is based on the assumption that the shifts or changes made in the Arabic text can hardly be attributed to the poetic licence or the creative potential of the self-translator. They should be seen in the light of bicultural competence of the self-translator as cultural mediator. This competence unfolds in his knowledge of the disparities between the readerships, socio-political structures and censorship rules of both the source and target languages and cultures. Consequently, the self-translator is also expected to designate and maintain the skopos of the target language text. Unlike the translator per se, the self-translator has the privilege of access to the intention of the source language text prior to its production . All these prerequisites contribute to the self-translator's decisions of introducing shifts and changes in the target language text through cultural mediation. Being written in English, the source language text is seen to have undergone cultural mediation too: a fact that leads to a conviction that Jabra was a 'double mediator'.
\end{abstract}

Keywords: self-translation, mediation, skopos

\section{Introduction}

\subsection{The Problem and Value of the Study}

In any self-translation practice, there seems to be a tendency to make drastic changes in the Target Language Text (TT). The motivation behind such changes is assumed to be the poetic licence or the creative potential of the self-translator. Being the original author of the Source Language Text (ST), the self-translator is seen a "dictator" who practices the utmost freedom with his text. The translator proper is usually denied such right and expected to be faithful to the original text. Nevertheless, when the present writer has acquainted herself with few examples of self-translation, she finds that the motivations for such presupposed freedom should be seen from a perspective other than the equivalence-oriented paradigm. Few studies have tackled this problem. For instance, Jung (2004) emphasizes that the changes in the TT are mainly due to the bicultural status of the self-translator who is supposed to account for the differences in knowledge base between the readers of ST and TT, English and German, respectively.

To the best knowledge of the present writer, no study about bilingual writers of Arabic and English, like Jabra Ibrahim Jabra, has dealt with this problem yet ; specifically, from the viewpoint and theoretical approach advocated here. However, the writer and the texts under study have been discussed according to the above-mentioned equivalence-oriented paradigm. Asfour (2009a:322) is primarily concerned with comparing the amount of freedom Jabra has practiced with that of his own, should he have translated that chapter. Accordingly, the motivations for such freedom are mentioned sporadically in his discussion.

\subsection{Hypotheses and Plan of the Study}

It is hypothesized that there are many motivations behind the changes undertaken by the self-translator in the TT, other than merely the poetic licence. The self-translator's competence in the languages and cultures of the ST and 
TT should assist him to mediate between the two texts. Therefore, it is also hypothesized that investigating self-translation in terms of the equivalence-based paradigm alone will not be fruitful. The application of the skopos theory rules may provide more tangible results in this respect. Moreover, it is hypothesized that the ST under study may have undergone mediation too since it is written in English but meant to depict the Arab culture for the English-reading audience.

It is the task of the present paper to prove the (in)validity of these hypotheses. This is undertaken by investigating the concept of self-translation in so far as its motivations and status are concerned by citing examples of self-translators. There will be a review of the theoretical framework in terms of which the examination of the text is done. Then, the text under study is analysed accordingly.

\section{The Concept of Self-translation}

The act of self-translation involves the rendering of ST into TT by the original writer of the ST. The concept has not been compartmentalized within one field rather the other. It is seen to occupy the fuzzy area between the domain of translation studies and that of literary studies. Though self-translation has been practiced by many men of letters such as Samuel Beckett and Vladimir Nabokov, it is rarely approved in literary circles. Similarly, translation scholars see the phenomenon more closely related to bilingualism than to translation per se .However, self-translators do not only master but choose to create in more than one language (Grutman, 1998:18). Beaujour (1989:39 as cited by Grutman, 1998: 18) also draws a clear-cut line between ordinary bilinguals who often shift languages with no conscious decision to do so, and the bilingual writers who deliberately decide which language to use at a time. Consequently, those writers should equally make vigilant a decision when they self- translate.

As a phenomenon, self-translation has a long tradition and continues to be widespread in several cultures. Previous investigations of self-translation have mainly been confined to two areas. Wilson (2009: 187) describes these areas as: one is concerned with what drives an author towards self-translation while the other considers issues of textual status and relationship, i.e., the self-translated text as having a different status to a 'proper' translation since it is instilled with the author's intention, and being a repetition rather than a reproduction.

The following examples will presumably illustrate these areas which have dominated the self- translation scene. Samuel Beckett has famously written in both English and French. He is often criticized for claiming to have translated his own texts between the two languages. Taking the original text as the authority, Bassnett and Lefevere (1998:31) call for denying the existence of any original text and consequently denying any translation in Beckett's work due to the vast differences between the English and French versions. They go so far as to assume, instead, that there are two versions of the same text which simply happens to be written by the same author in different languages. On the other hand, people like Connor (1989:27) feel it is safe to assume for Beckett an oeuvre of "pairs of identical twins". Beckett's case in self-translation, however, is not the rule for he represents a 'league of his own 'by producing simultaneously. English and French versions of his work(Grutman, 1998:20).

A similar author, Federman(http://www.federman.com/rfsrce2.htm) insists that Beckett's texts in English and French should not be read as translations or substitutes but as complementary to one another. Federman likens his case of "schizophrenic bilingualism" to Beckett's, but he admits resorting to what he calls "the horror of self-translation", namely, fear of betrayal or loss of the original because of the temptation of finding the text in another language. His actual reasons for self-translation may be the possibility of gain, rather than loss, in the TT by having the chance of correcting the errors of the original. The original creative art, for Federman, always happens in the dark, in ignorance and in error while self-translating is performed in the light (of the original): in knowledge.

But the very act of working" in the light" may lead to misinformation and misinterpretations as in the case of Tagore's translations of his own works, which is seen to be responsible for the decline in his popularity and fame. Tagore received the Nobel Prize for Literature in 1913; a year after the publication of his self-translated poems into English, nonetheless, criticized for attempting at "simplification and ruthless suppression" of native associations or sensibility in his self-translated texts (Sarkar, 2002:114). The admiration of the westerners was mainly rooted in Tagore's unparalleled simplicity and oriental mystique which came to be the hallmark of the poetry of piety (Sarkar, 2002: 114). Besides, Tagore has substituted terms which he thought would be familiar to western understanding or introduced new elements to aid such understanding, which has lead to accuse him of being " a purveyor of his merchandise to customers of other lands who took fancy in his wares" (Sarkar, 2002: 119) Tagore, then, was after a wider readership and he was successful by all standards. The dilemma with his critics was that they could not draw a line between translation proper which requires subordination and equivalence to the original text, and self-translation where the authority of the author is what really matters. 
So, by following the general rules of self-translation, Tagore did nothing wrong. He might have used universal fame. The strategy of self-translation may also be resorted to so as to "assert a voice that has been suppressed". Attar (2005), a self-exiled multilingual ,recounts her ordeal of trying to have her first novel published in her mother tongue: Arabic. She had to translate it into English in response to continuous attempts to stifle and silence her voice as a novelist, i.e., by censorship in the Arab world (Attar, 2005:134). Attar's novels are based on biographical experiences and historical research, they are socio-political accounts of her homeland, Syria, in the 1950s and 1960s. The author sees her work as an embodiment of her longing for freedom and the struggle to rid of restrictions of family, religion ,culture , and nation (Attar, $2005: 136$ ). This could be the very reason behind publishing the TT in English and expecting a wider readership ; just as it was the main reason for the hurdles maintained by censors to prevent its publication in Arabic, in the beginning (Note 1.). The motivation for writing and self-translating such texts is stated by the author herself who uses the exiled self as a frame of reference to subvert the dominant discourses of cultural authority and to shape the politics of writing/ translating in modern times.

Exile has often been a motive for self-translation. For instance, it has played a major role in Vladimir Nabokov's choice to write and translate his works in more than one language. Raised a polyglot, the originally Russian Nabokov is seen to represent a cosmopolitan image of a writer. He was forced to leave Russia after the Bolshevik revolution. Then, he wrote in Russian but his readership turned out to be limited in scope: only the Russian emigre' community in Europe read him. He moved to the United States of America, eventually, and started to write in English(Yarsawich,2007:4). Nabokov also self-translated many works written originally in Russian, into English .Thus, his readership grew exponentially all over the world. It is said that he has not been satisfied with translations of his works by others, he tended to self -translate his Russian works into English and vice versa(see Kimmel, 1998 and Osimo, 1999).

Dissatisfaction with others' translations of one's own text may be a very good reason for taking up the task of self-translation. Here, there is an attempt to give the practice a higher status than translation proper. In verse self-translation, uniquely, the opposite opinion is made by Whyte (2002:69) who argues that if translation is about crossing barriers, contaminating one language with the experience and rhythms of another, self-translation occurs in situations of exile or of crude subjugation, where one language is attempting to take the place of another.

To sum up, self-translation is practiced to increase the number of readers or to escape the confines of one language (or its censorship) to another. It is a manifestation of the essential human desire for recognition in another language and culture, or simply the desire to conquer nostalgia, loss of identity and invisibility of the exiled author. Now, the motives of self-translation and its standing have become clear, a question of import may strike one's mind: how can the author achieve visibility in the readers' realm through self-translation? A possible answer could be to adopt cultural mediation as performed by the translator proper.

\section{Some Theoretical Considerations}

\subsection{The Translator as Mediator}

Mediation in language is defined by Beaugrande and Dressler (1981:182) as" the extent to which one feeds one's current beliefs and goals into the model of the communicative situation". This is useful when the reader uses his knowledge of a text in the processing of the text in hand, a matter that can be applicable to the translator who is the reader of the ST and producer of TT.

Translation proper is described as mediation, namely, there is a translator between two languages, mediating between them ( Stecconi, 2004 as cited by Pym, 2010:77). The work of the translator involves mediation between two parties: the producer of ST and the receivers of TT for whom mutual communication might otherwise be problematic because of the disparities between the two cultures ( Hatim and Mason, 1990: 223). The translator, consequently, needs not be only bilingual but also bicultural so as to be able to facilitate cross-cultural understanding.

But the concept of cultural mediation has been developed to be a strategy of translation, and seen in terms of degrees: "the extent to which translators intervene in the transfer process, feeding their own knowledge and beliefs into their processing of a text"( Hatim and Mason, 1997:122). The translator's mediation, therefore, could be minimal, maximal or partial depending on how much of the ST features he intends to preserve. The less features he relays, the higher degree of mediation he will have performed and vice versa (Note 2.). The degree of mediation may largely be justified according to who and/what initiate the translation action, an important component of skopos. 


\subsection{A General Overview of Skopos Theory}

Skopos is the Greek for purpose or aim. It has become the title of a translation theory that shifts the interest in the age-old equivalence-based translation paradigm towards the priority of TT's purpose .According to this theory , translation is not only a process of transcoding but a specific form of action, the purpose or skopos of which must be determined before translation begins (Schaffner,1998: 235).Vermeer (1992:11) insists that the skopos is not in the ST but it may arise from the initiator's intention, and it is the task of the translator to make the TT fit in the intended skopos. The translator has been dubbed as the 'expert' who is supposed to know how to bring about cultural communication and lead it to its intended skopos (Vermeer, 1992:11). In an elaborate statement, the skopos rule is when

"Each text is produced for a given purpose and should serve this purpose. The skopos rule thus reads as follows: translate/interpret/speak/write in a way that enables your text/translation to function in the situation in which it is used and with the people who want to use it and precisely in the way they want it to function."

(Vermeer, 1989:20, translation from Nord, 1997:97)

The second rule of the theory is 'coherence rule'. It states that the TT must be sufficiently coherent to allow the intended receivers to comprehend it, given their assumed background knowledge ( Schaffner,1998: 236) The TT must be consistent with the cannons and moral and ethnic principles of the target language and culture. Hence, the TT is expected to consider the target readership's background knowledge and situational circumstances.

To avoid accusations of unfaithfulness, the skopos theory offers a third rule: the 'fidelity rule'. It concerns "intertexual coherence" between TT and ST; and merely states that there must be some relationship between the two(Schaffner,1998:236). Such relationship can be described in terms of presumed match between the ST information as received and interpreted by the translator and his encoding of it for the TT readers. But the fidelity rule is considered secondary to coherence rule, and both are subordinate to the skopos rule. For instance, the skopos of the translation will determine the appropriate genre of the TT. The TT genre, which is dictated by coherence, is thus a consequence of the skopos, and thereby secondary to it. An epic like Homer's Odyssey may be translated into a novel, its genre has thus changed because a particular skopos considers this appropriate in the TT (Vermeer, 2000: 232). Definitely, a match can also be identified between the ST and TT, which proves the fidelity rule, but subordinated to skopos.

\section{The Self-translator as Cultural Mediator}

\subsection{Preliminaries}

In principle, self-translation is not very much different from translation proper. Both involve rendering ST into TT. Besides, the one in charge of this rendering is supposed to master not only the two languages but also their cultures. These preconditions should help either of them to mediate between the two texts so as to maintain the purpose of the translation action, in the first place. Mediation and maintaining the skopos may result in significant changes in the TT. Accordingly, the translator proper may be blamed, at least by the equivalence-based paradigm proponents, for not being faithful to the ST. Judged from the skopos theory perspective, the self-translator should be impregnable to such criticism.

\subsection{Jabra: The Bilingual Writer and Translator}

A Cambridge graduate and creative intellectual, Jabra was a novelist, a short story and essay writer, a poet, a literary critic and a translator into Arabic of Shakespeare's plays and sonnets and more than thirty English literary classics (See Jabra, 1995.One of his novels البحث عن وليد مسعود is ranked second of the best hundred Arabic novels by the Federation of Arab Writers( See ar.wikipedia.org). Jabra was born in 1920 in Palestine and was forced into exile after the 1948 events. He went to Iraq, where he worked and lived till his death in 1994 (Jabra, 1995; Asfour,2009b; Wikipedia.com)

\subsection{Jabra: The Self-translator}

Despite his overwhelming experience in translation per se, Jabra is known to have one published attempt to self-translation: chapter 13 of his novel Hunters in a Narrow Street. He finished writing the novel in English in 1952 and was published in 1960 in London. The novel, as a whole, was translated, in 1974, into Arabic by Professor Mohammad Asfour, a student of Jabra's at the time. Asfour (2009a:322) emphasized that chapter 13 of the novel had already been self- translated by Jabra into Arabic. Given the choice by Jabra, Asfour preferred not to translate the chapter and made use of Jabra's self-translation for he believed [it was more truthful to Jabra's intentions if he had written the novel in Arabic] ( Asfour, 2009a:322) (Note 3.).It turned out that the 
self-translated chapter had been included by Jabra as a short story under the title أصوات أللات in his only collection of short stories (Note 4.).

\subsubsection{Bilinguality, Motivation and the Temporal Space}

Before attempting at discovering the motivation behind Jabra's self-translation action, it seems more appropriate to explore why he has written the novel in English, in the first place. Being a bilingual, Jabra (1994:134) admitted that [ till that day of 1951, words in English would come to me whenever I wanted to write poetry] (Note 5.) This is a natural tendency expected to happen to many bilingual men of letters. But the question is much more complicated than it appears to be. Jabra was not only a bilingual writer but also a forced exile who did not live in an English-speaking country like Nabokov, for instance. He chose to live in Iraq, an Arab country. In most of his creative works, Jabra was haunted by the Palestinian outside Palestine and insisted that his work was a mixture of nostalgia and anticipation. He was aware that part of the failure to save Palestine lay in the backward cultural and socio-political conditions in the Arab society as a whole. In the novels he wrote after moving to Iraq, Jabra was

"...grappling with the endless theme of a Palestinian exile in an Arab world which he loved and observed and wanted to change"

(Jabra, 1979:86)

For Jabra, Baghdad (the capital of Iraq), once ravaged by centuries of neglect, was now going through the agonies of "rebirth' and could offer him love and fame( Jabra, 1979:82) So, his aspiration was to change, a theme he attempted to display in his' Hunters in a Narrow Street'. The novel dealt with socio-political matters that Jabra wanted to present to a western readership in its own language: English. But Jabra was careful in such presentation by avoiding the sentimentality, hastiness and shallowness that characterized the political Arabic writings at that time (Asfour, 2009b:39).

The motivation of the self-translation action may be to expand the readership, financial reasons or simply the initiator or the publisher who commissioned the translation. The justification for such reasons can be the long span of time between writing the novel in 1951-1952 and its publication in 1960. At the beginning, Jabra might not have found a publisher for his novel so he decided to self-translate one of its chapters and had it published as a short story hoping to achieve success among the Arab readers first. The ST, however, is so successful that it has been published many times since then. In the forward of the 1997 edition, Roger Allen stresses that the novel is relevant today as on the day of its first publication in 1960(Jabra,1997:6).

\subsubsection{Biculturality and the Self-translator as Cultural Mediator}

By writing about events, thoughts and socio-political conditions deeply immersed in his Arab culture in the language of another culture: English, Jabra was a cultural mediator. Hence, it should be understood from the outset that there has been some mediation in the ST with regard to consideration of the ability of the English readership to comprehend the Arabic cultural references, as will be seen below. But, self-translating the same text should require another cultural mediation of the ST references so as to make them comprehensible for the TT readers. This last mediation is supposed to bridge the gap between the different kinds of knowledge between the ST and TT readers.

In the following sections, Jabra's decisions as self-translator playing the role of cultural mediator are highlighted. For ease of reference, citations of examples are documented by numbers of pages only. The ST (English text) is listed in the References as( Jabra,1960) and the TT( Arabic text) as ( Jabra,1974).

\subsubsection{The Creative Potential}

In the ST, there are two cases of Jabra's poetic creativity. The first one is the poem recited by one of the characters, Adnan in the café', it goes as follows

\footnotetext{
"Although the women glorify you,

A symbol of their ancient lust,

Upon a palm-tree they'll crucify you

With mouth wide open for midday dust.

They'll dance around your quartered limbs

And pour their arak at your feet

And tell you of their secret whims
} 
And seize your genitals to eat.

They'll eat your eyes in their despair

And cry to see your lips unkissed,

And as they dance their backs they'll bare

And thorns will grow where they have pissed"

A self-translator is expected to give an Arabic version. Jabra, however, prefers to tell the TT readers some of the content in prose, in the narrator's words:

"لا أذكر أبيات قصيدته بالنص ولكن لن انسى فحواها وهو ان النساء يعظمنك رمز الشبقهن القديم لكي يصلبنلك يوما على نخلة وفمك فاغر الغبار

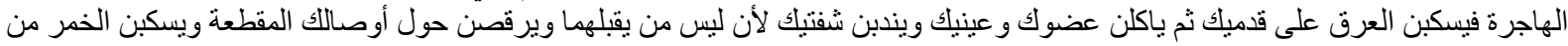
جديد ثم يفرغن مثاناتهن فينمو الشوك كثيفا حول بقاياك" (p.89 )

Originally, the poem is supposed to have been written in Arabic and recited before Arab men in the café', but it is given in an English poetic form so as be effective for the English readers of ST while the content may not be new or shocking for them. It is this very content that moves the listeners and leads to a lengthy discussion of the poem in the next three pages of the ST. Cultural mediation is practiced by Jabra merely when he has composed the poem according to his deep knowledge of English literary conventions, which facilitates the ST readers' comprehension .But he decides to render it as a paraphrase or in prose in Arabic since the content may have socio-political implications as the ST unfolds later.

In another place of ST, the narrator who is supposed to converse in English with English natives, says,"Prompted by a wicked whim I recited lines I had written during my undergraduate days" (p.87).

The poem is about Jerusalem, the TT goes as

$$
\text { فدفعني خاطر لتلاوة ابيات من قصيدة كنت كتبتها بالأنكليزية أيام در استي الجامعية....(p.103) }
$$

But one of the Englishmen says, "That's an Arabic poem, I suppose"."Yes", I said. (p.87)

Then, Jabra's TT becomes

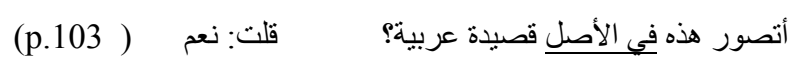

The underlined words in Arabic show the additions made by Jabra as a means of mediation motivated by the different readerships.

\subsubsection{Cultural Aspects}

The bicultural knowledge of Jabra has enabled him to deal with cultural references and cultural signs of local flavour.

\section{A) Cultural References}

During conversing on historical facts of Babylon, one of the English people says. '

"Nebuchadnezzar did not eat grass with the swines in Babylon ". (p87), which is rendered into

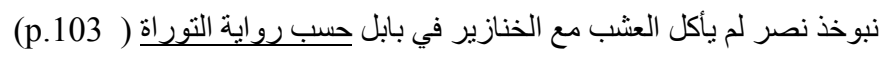

The use of the allusion in the ST indicates a shared knowledge with the readers .In TT, the underlined additions are assumed to ensure the comprehensibility of the TT for its readers.

Jabra resorts to change the allusion to guarantee acceptability as in

"...has not the soil been sodden with the blood of Adonis and Christ?"(p.88), which becomes:

$$
\text { ألم يسق ترابك دم تموز و المسيح؟) (p.10) }
$$

The allusion to Adonis in the ST is changed to the underlined word in TT which is taken from the old myths of Mesopotamia and seems understandable to the TT readers. The word Temouz was in vogue in the cultural circles at that time (Asfour, 2009a: 338)

\section{B) Cultural Signs of Local Flavour}

The ST is full of cultural signs of local flavour. Signs such as istikan or brass pitcher are culturally known in Baghdadi cafes'. They are relayed when rendered into Arabic, of course. The use of "boy" (p.79) to call the waiter in the cafe', which is given as

$$
\text { " باولد"( } 93 \text { (P. }
$$


can never be acceptable but in a Baghdadi society because it may have a derogatory sense in other Arab countries. Then, the waiter says" immediately sir" (p.79) which is rendered into

$$
\text { "تدلل"(p.93), (p.79) }
$$

a polite Baghdadi lexical item to express readiness to do what is required from the one who utters it.

Other culture-bound expressions and their renderings that prove Jabra's cultural mediation are listed as follows

"our women's gatherings"(79) into

$$
\text { قبو لاتتا"(p.94) }
$$

Lucky boy" and "Lucky bastard"(p.89) into

$$
\text { "أيدك بالدهن" و "تونس" (p.105) }
$$

An example of substitution because of cultural mediation with the TT readers can be illustrated here. The narrator's monologue " I remembered the disputants in the casino by the river less than a mile away...."(p. 86) is given as

$$
\text { "تذكرت جماعة المتناقثين في الكازينوفي شار ع أبي نؤ اس على مبعدة أقل من ميل"(p.104) }
$$

The substitution of "by the river" by the underlined words in Arabic indicates Jabra's respect of his TT readers' common knowledge that the street by the river is well-known for its many café's, which may look unimportant for the ST readers.

\subsubsection{Additions}

Many additions have been observed in the TT. Only those seen to have contributed to the comprehensibility of the TT by its readers will be discussed here. For instance, the following sentence

"He sat down and tea was ordered for him "(p.81) is given in TT as

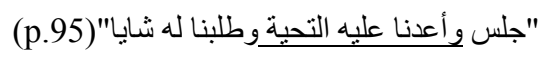

The adding of the underlined words (we repeated our greetings) has a cultural significance. Actually, it is a must-be- done social mode of greeting among Iraqi men. A new comer is usually greeted at once, but if he decides to sit with you, he must be greeted again. A cultural mediation is at work here.

Another addition also takes the TT reader's knowledge into consideration. Jabra describes Towfiq, a character in the novel as" he wore a Bedouin cloak"(p.80) but in Arabic, it is

$$
\text { "كان يرتدي عقالا و عباءة بدوية" (p.95) }
$$

The addition of the underlined word 'iqal' seems inevitable since a Bedouin clothing must contain both pieces, inclusion of iqal in the ST has no significance to the ST readers who may not share the same knowledge about the Bedouin clothing.

Other additions are made to compensate for the lack of knowledge of TT readers for it should be remembered that the TT is a short story and there is no chance of cross reference to much of the information indicated in those additions. The underlined examples in the following are the additions opted for by Jabra.

"when I asked my pupil whether she would be there too"(p.79)

$$
\text { "ولما سألت تلميذتي أذا هبة هي الى العشاء عند خالتها"(p.94) }
$$

" the grammar I was teaching her"(80)

$$
\text { " (p.94)" النحو الأنكليزي الذي كنت أدرسها اياه }
$$

"when he went to college"(p.85)

$$
\text { "عندما درس في احدى كليات بغداد"(p.100)" (عبد) }
$$

But Brian was there"(p.85)"

$$
\text { غير أن بر ايان فلنت كان هناك (p.100) }
$$

\subsubsection{Taboos}

Jabra has not been consistent in rendering taboos into Arabic. For example, Towfiq says about the women in the city," ...because they are never sexually satisfied by their men"(p.82). In TT, it goes as

$$
\text { " . . لأن أزو اجهن عاجزون عن تمتيعهن ..." (p. 96)" }
$$


Jabra has used "men" in the ST for it is more general, namely, applies to husbands and partners for the English readers. But when men is rendered into husbands in TT, Jabra is trying to cope with the Arab cultural and moral rules which don't tolerate sexual relation outside marriage .

Towfiq criticizes love as presented by modern Arab writers, "..who, nevertheless, out of the whole domain of love will only get a bit of masturbation"(p.83), and rendered into Arabic as

$$
\text { "ومع ذللك لايحصلون من ملذات الحب كلها الا على شئ من جلد عميرة"(p.98) }
$$

Success of euphemisms in the TT cannot always be guaranteed for they may harm the content. Asfour(2009a:335) argues that the choice of the Arabic euphemistic image may have mitigated the shock of the TT reader, but has caused a contradiction when Towfiq admits later that he does not believe in using euphemisms in his speech. Censorship rules of Arabic publications might have been considered here.

In another example, Towfiq is in rage and yells, "You son of a bitch"(p. 84) which is given in TT as

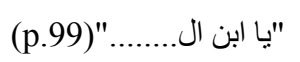

The omission of such taboo may be placed within the cultural mediation for the blank will be understood, by the TT readers, to stand for a dirty word of insult. On the other hand, Jabra would not mind opting for another taboo and vernacular word in Arabic when rendering

" ...with the sweat of your arse"(p.82)

$$
\text { (p.97)"بعرق جحرك"....." }
$$

It has become obvious that Jabra has taken the readership of both the ST and TT into consideration. It is the readership that initiates the self-translation action, a fact validated by the relevance of skopos.

\subsubsection{Relevance of Skopos Theory}

The skopos rules are seen to have been maintained all through the self-translation action. The skopos is to have a short story in Arabic as might have been initiated or commissioned by the publisher or decided by the self-translator himself. The TT is given the autonomy of a separate text; not a chapter in a novel.

By following the linguistic cannons and cultural principles of the TT language and considering the TT's readership, Jabra achieves the' coherence rule' . To this end, cultural mediations have been performed and self-translational decisions have been taken such as additions, deletions, and expansions in the TT.

As for the' fidelity rule', a sort of match can be observed between ST and TT. The names of characters, their ideas and the order of events are relayed in the TT in spite of the claim of autonomy of the short story. The matching is real, otherwise the TT would not have fitted as a chapter in the complete translation of the novel.

\section{Conclusions}

The discussion above reveals that Jabra has resorted to changes, additions and deletions in his self-translation not because of the poetic licence alone. The practice is mainly invoked by other motivations, including Jabra's biculturality and extensive knowledge of the socio-political structure and moral principles of the TT readers. Through the decisions he takes, a tendency towards cultural mediation unfolds and a consistency with the skopos rules evolves. Jabra's mediations, however, is found not to be restricted only to the process of self-translation. It is observed that he has performed the role of cultural mediator when he has chosen to write the ST in English. Displaying the Arab culture in English language has required cultural mediation in order to ensure its compatibility with the English readers' expectations and its comprehensibility by them. Hence, a 'double cultural mediation' is carried out. After all, Jabra has not been writing in dark and self- translating in light, as might Federman(see 2. above) have contended. Jabra Ibrahim Jabra has written and self-translated in light only.

\section{References}

Asfour, M. (2009a). Dirasaat filTarjama wa Naqdiha. Beirut: Arab Foundation for Studies \&Publishing. Asfour, M. (2009b). Narjis wa l Maraya.Beirut: Arab. Foundation for Studies \& publishing.

Attar, S. (2005). Translating the Exiled Self: Reflections on Translation and Censorship. Intercultural Communication Studies, XIV(4), 131-147.

Bassnett, S., \& Lefevere, A. (1998). Constructing Cultures: Essays on Literary Translation. UK: Multilingual Matters LTD.

Beaugrande, R. A. D., \& Dressler, W. (1981). Introduction to Text Linguistics. London \& New York: Longman.

Connor, S. (1989). Traduttore, Traditore: Samuel Beckett's Translation of Mercier et Camier. Journal of Beckett 
Studies, 11(12), 27-46.

Federman, R. (2012). A Voice within a Voice: Federman Translating Federman. Retrieved from http://www.federman.com/rfsrce2.htm

Grutman, R. (1998). Auto Translation. In M. Baker (Ed.), Routledge Encyclopedia of Translation Studies (pp. 17-20). London: Routledge.

Hatim, B., \& Mason, I. (1997). The Translator as Communicator. London \& New York: Routledge.

Hatim, B., \&Mason, I. (1990). Discourse and the Translator. London: Longman.

Jabra, J. I. (1960). Hunters In a Narrow Street. London: Heinemann.

Jabra, J. I. (1974). Sayadoon fi Shari' Dhaiyiq. (Trans.)M. Asfour.Beirut: Dar Aladab.

Jabra, J. I. (1979). The Palestinian Exile as Writer. Journal of Palestine Studies, 8(2), 77-87. http://dx.doi.org/10.1525/jps.1979.8.2.00p01177

Jabra, J. I. (1995). The First Well: a Bethlehem Boyhood. (Trans.) I. Boulata. Fayetteville: The University of Arkansas Press.

Jabra, J. I. (1997). Hunters In a Narrow Street. London: A Three Continent Book.

Jung, V. (2004). Writing Germany in Exile -The Bilingual Author as Cultural Mediator: Klaus Mann, Stefan Heym, Rudolf Arnheim and Hanna ArendtJ. Journal of Multilingual and Multicultural Development, 25(5-6), 529-546. http://dx.doi.org/10.1080/01434630408668923

Kimmel, L. (1998). Nabokov as Translator. Retrieved from http://www.leighkimmel.com/writing/academicpapers/Nabokov2.shtml.Retrived on 5/4/2012

Nord, C. (1997). Translating as a Purposeful Activity: Functionalist Approaches Explained. Manchester: St. Jerome.

Osimo, B. (1999). Nabokov's Self-translations: Interpretation Problems and Solutions in Lolita's Russian Version. Sign System Studies, 27, 215-233.

Pym, A. (2010). Exploring Translation Theories. London \& New York: Routledge.

Sarkar, S. (2002). Tagore in Translation: A Case for Revaluation. In M. Ray (Ed.), Studies in Translation (pp. 112-121). New Delhi: Atlantic Publishers.

Schaffner, C. (1998). Skopos Theory. In M. Baker (Ed.), Routeldge Encyclopedia of Translation Studies (pp. 235-238). London: Routledge.

Vermeer, H. J. (1992). Translation today: Old and New Problems. In Mary Snell-Hornby (Ed.), Translation Studies: An Interdiscipline (pp. 3-16). Amsterdam: John Benjamin.

Vermeer, H. J. (2000). Skopos and Commission in Translational Action. In L. Venuti (Ed.), The Tanslation Studies Reader (pp. 221-232). London \& New York: Routledge.

Whyte, C. (2002). Against Self-translation. Translation \& Literature, 11, 64-71. http://dx.doi.org/10.3366/tal.2002.11.1.64

Wilson, R. (2009). The Writer's Double: Translation, Writing and Autobiography. Romance Studies, 27(3), 186-198. http://dx.doi.org/10.1179/174581509X455150

Yarsawich, C. (2007). Speaking in Tongues Vladimir Nabokov as a Multilingual. Honors Junior/Senior Projects. Paper 49. Retrieved from http://hdl.handle.net/2047/d1000807x

\section{Notes}

Note 1. The problem of the Self and the Other in the postcolonial context is out of the scope of the present study.

Note 2. Hatim and Mason (1997) analyse some texts to prove this opinion. Their focus has been on how much cohesion, discourse and features of text are maintained.

Note 3. The translation is the present writer's.

Note 4. The title in English is literally' Voices of the Night'. It was published within a collection of other short stories in 1956.There are four editions of this collection, the last of which is in 1981.

Note 5. The translation is the present writer's. 